closely resembles Meleney's gangrene in appearance and cause. ${ }^{23}$ Several factors contributed to the delay in diagnosing amoebiasis in our patient-the absence of amoebas in the stools, the negative complement fixation test result, the white abscess pus instead of the classical "anchovy" pus, the fact that amoebas are not visible in Gram

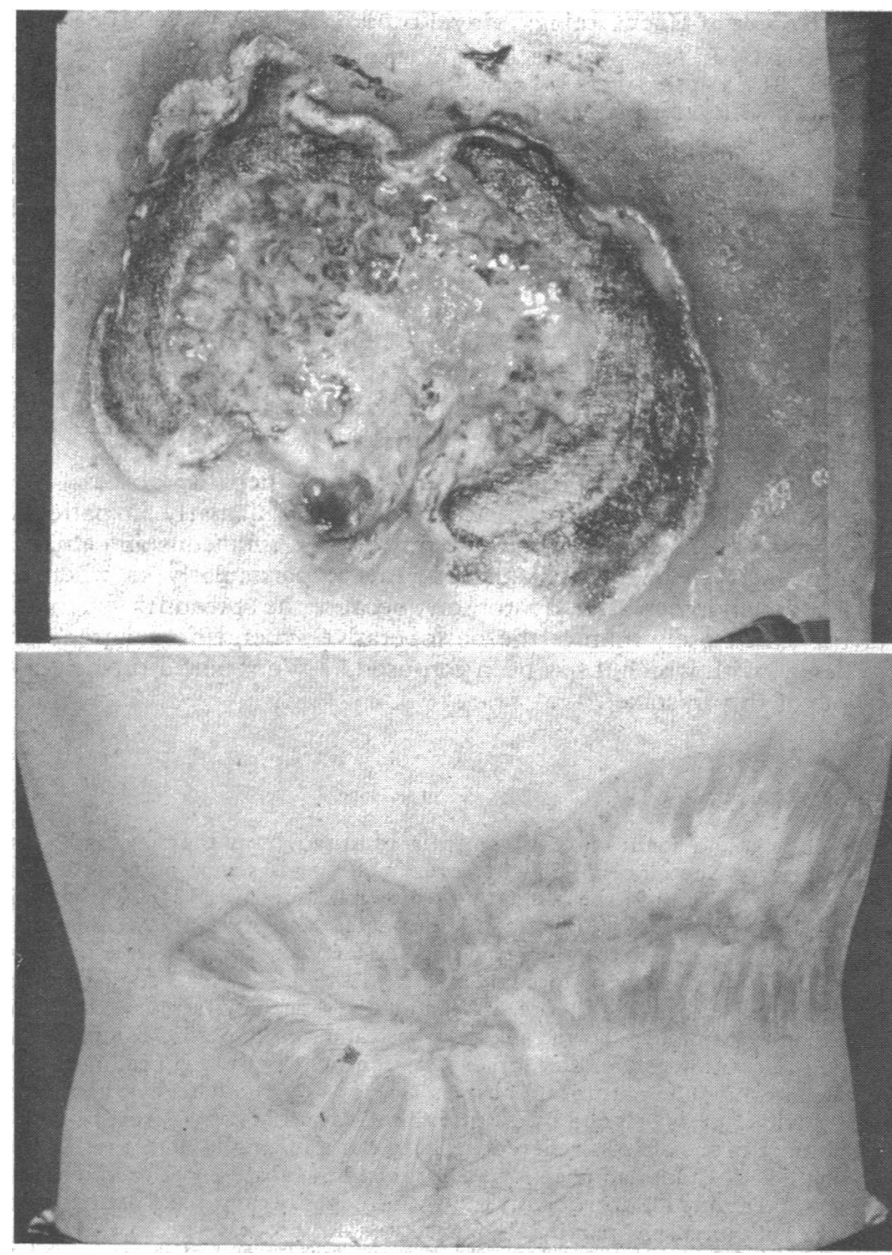

Top: Postoperative cutaneous gangrene of abdominal wall due to amoebiasis Appearance bears striking resemblance to Meleney's gangrene. Bottom: Appearance of abdomen three months after beginning emetine. Healing is complete but with extensive scarring.

stained films of pus, and the recognised difficulty in diagnosing amoebic abscesses in the left lobe of the liver. ${ }^{4}$ The complement fixation test for amoebiasis has now been superseded by the more reliable immunofluorescence test. ${ }^{5}$

In a patient with progressive gangrene of the abdominal wall it is essential to exclude amoebiasis before accepting the alternative diagnosis of synergistic bacterial gangrene of Meleney.

1 Sanderson IR, Walker-Smith JA. Indigenous amoebiasis: an important differential diagnosis of chronic inflammatory bowel disease. Br Med $\mathcal{f} 1984 ; 289: 823$. Cole WH, Heideman ML. Amebic ulcer of the abdominal wall following appendectomy with drainage. $\mathcal{F} A M A \quad 1929 ; 92: 537-40$.

3 Joseph L, Bhat HS. Amoebic ulceration of the abdominal wall. Br F Surg 1967; 54:187-8.

Vakil BJ, Mekta AJ, Desai HN. Atypical manifestations of amoebic abscess of the liver. $\mathcal{F}$ Trop Med Hyg 1970;73:63-7.

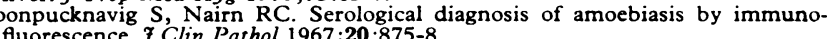

Accepted 6 fune 1985)

Withington Hospital, Manchester M20 8LR

L TURNER, MD, FRCs, consultant surgeon

D M JONES, MD, FRCPATH, consultant bacteriologist

Department of Pathology, Stopford Building, University of Manchester

J DAVSON, MB, FRCPATH, honorary curator

Correspondence and requests for reprints to: Mr Turner.

\section{Antagonism of ceftazidime by chloramphenicol in vitro and in vivo during treatment of Gram negative meningitis}

Following the work of Jawetz and his colleagues in the $1950 \mathrm{~s}^{1}$ a considerable body of evidence has accumulated that bacteriostatic and bactericidal drugs may antagonise each other in vitro ${ }^{2}$ and in vivo in both animals ${ }^{3}$ and man. ${ }^{5}$ Despite this many authorities believe that antagonism between bacteriostatic and bactericidal drugs is unimportant, and the use of such combination treatment in bacterial meningitis is still widely practised. We have observed definite and clinically important antagonism, both in vitro and in vivo, between chloramphenicol and the cephalosporin ceftazidime during treatment of a young infant with salmonella meningitis. The combination treatment failed to eradicate the infection but subsequent treatment with ceftazidime alone was successful.

\section{Case report}

A previously normal $2 \frac{1}{2}$ month old boy was admitted in November 1984 with a two day history of fever, diarrhoea, abdominal distension, and poor feeding. Twelve hours after admission he had generalised convulsions and a rectal temperature of $40^{\circ} \mathrm{C}$. The cerebrospinal fluid was bloodstained and a cell count could not be performed; the glucose concentration, however, was $2.0 \mathrm{mmol} / 1$ (36 mg/100 ml) (blood glucose concentration $6.7 \mathrm{mmol} / 1 ; 121$ $\mathrm{mg} / 100 \mathrm{ml}$ ). Gram staining showed Gram negative rods, and both cerebrospinal fluid and blood cultures yielded Salmonella enteritidis group D.

Intravenous treatment was begun with chloramphenicol $75 \mathrm{mg} / \mathrm{kg} / \mathrm{day}$, later increasing to $100 \mathrm{mg} / \mathrm{kg} /$ day, together with ceftazidime $100 \mathrm{mg} / \mathrm{kg} /$ day, in three divided doses. The child showed little response over the next four days, with persistent fever. A second sample of cerebrospinal fluid taken on the fourth day of treatment contained a white cell count of $136 \times 10^{6} / 1(89 \%$ polymorphs), protein $1.59 \mathrm{~g} / \mathrm{l}$, and a glucose concentration of $1.6 \mathrm{mmol} / \mathrm{l}(29$ $\mathrm{mg} / 100 \mathrm{ml}$ ) (blood glucose concentration $4.7 \mathrm{mmol} / 1 ; 85 \mathrm{mg} / 100 \mathrm{ml}$ ). Gram staining gave a negative result and a blood culture was sterile, but again culture of cerebrospinal fluid grew $S$ enteritidis.

In vitro tests of serum and cerebrospinal fluid taken at that time showed that the serum could inhibit the growth of an inoculum of the salmonella at a dilution of $1 / 2$, and the cerebrospinal fluid at a dilution of $1 / 16$, but that neither fluid could kill the organism at any dilution (table). The minimal inhibitory concentrations of chloramphenicol and ceftazidime for the salmonella were $4 \mathrm{mg} / 1$ and $0.5 \mathrm{mg} / 1$, respectively. The minimal bactericidal

Concentrations of ceftazidime and chloramphenicol in serum and cerebrospinal fluid and in vitro bacteriostatic and bactericidal activities of serum and cerebrospinal fluid against isolated strain of salmonella. (Minimal inhibitory concentration and minimal bactericidal concentration of ceftazidime $0.5 \mathrm{mg} / \mathrm{l}$; minimum inhibitory content of chloramphenicol $4 \mathrm{mg} / \mathrm{l}$ )

\begin{tabular}{|c|c|c|c|c|}
\hline & \multicolumn{2}{|c|}{26 November } & \multicolumn{2}{|c|}{30 November } \\
\hline & Serum & $\begin{array}{c}\text { Cerebrospinal } \\
\text { fluid }\end{array}$ & Serum & $\begin{array}{l}\text { Cerebrospinal } \\
\text { fluid }\end{array}$ \\
\hline Growth of salmonella & - & + & - & - \\
\hline $\begin{array}{l}\text { Ceftazidime }(\mathrm{mg} / \mathrm{l}) \\
\text { Chloramphenicol }(\mathrm{mg} / \mathrm{l})\end{array}$ & $\begin{array}{l}1.53 \\
5.4\end{array}$ & $\begin{array}{r}15 \cdot 3 \\
8 \cdot 0\end{array}$ & $234 \cdot 6$ & 31.5 \\
\hline Inhibitory dilution & $1 / 2$ & $1 / 16$ & ND & $1 / 32$ \\
\hline Bactericidal dilution & -1 & -1 & ND & $1 / 32$ \\
\hline
\end{tabular}

$\mathrm{ND}=$ Not done

On 26 November treatment was with ceftazidime plus chloramphenicol, each 100 $\mathrm{mg} / \mathrm{kg} /$ day in three divided doses, and specimens were collected seven hours after last dose. On 30 November treatment was with ceftazidime $150 \mathrm{mg} / \mathrm{kg} / \mathrm{day}$ alone in four divided doses, and specimens were collected three hours after last dose.

concentration of ceftazidime was $0.5 \mathrm{mg} / \mathrm{l}$, identical with the minimal inhibitory concentration. Concentrations of the antibiotics in serum and cerebrospinal fluid were measured by high pressure liquid chromatography. The cerebrospinal fluid, which had yielded salmonella on culture and failed to kill the organism in vitro, was found to contain $15.3 \mathrm{mg}$ ceftazidime and $8.0 \mathrm{mg}$ chloramphenicol/l (table). This amount of ceftazidime was 30 times greater than the minimal bactericidal concentration and should have been more than enough to kill the organism. This result suggested antagonism of ceftazidime by chloramphenicol in vivo.

Chequerboard titration of all possible concentrations of chloramphenicol and ceftazidime against the salmonella disclosed antagonism in vitro. Titration showed that when used alone ceftazidime at a concentration of 0.5 $\mathrm{mg} / \mathrm{l}$ (the minimal bactericidal concentration) killed the organism but that when combined with chloramphenicol $4 \mathrm{mg} / \mathrm{l}$ or more the combination was bacteriostatic but not bactericidal at concentrations up to $16 \mathrm{mg}$ ceftazidime/1.

In view of these findings chloramphenicol was stopped and treatment continued with ceftazidime alone at $150 \mathrm{mg} / \mathrm{kg} /$ day in four divided doses. 
The patient went on to make an uneventful recovery after seven days of intravenous ceftazidime alone. A specimen of cerebrospinal fluid taken during single drug treatment contained $31.5 \mathrm{mg}$ ceftazidime $/ \mathrm{l}$. The specimen was sterile on culture and both inhibited and killed the standard inoculum of salmonella in vitro at a dilution of $1 / 32$ (table). The concentration of ceftazidime and the inhibitory dilution were both twice that obtained with the lower dose of the drug, and in retrospect there was probably no need to have increased the dose when chloramphenicol was discontinued.

\section{Comment}

These findings are clear evidence of antagonism between the bacteriostatic agent chloramphenicol and the bactericidal ceftazidime and support the view that such combinations are undesirable in the treatment of meningitis. When a cephalosporin such as ceftazidime is used to treat Gram negative meningitis it should not be combined with chloramphenicol.

1 Jawetz E, Gunnison JB, Speck RS, Coleman VR. Studies on antibiotic synergism and antagonism: the interference of chloramphenicol with the action of penicillin. and antagonism: the interference

2 Rocco V, Overture G. Chloramphenicol inhibition of the bactericidal effect of ampicillin against Haemophilus influenzae. Antimicrob Agents Chemother 1982;21:349-51.

3 Lepper MH, Dowling HF. Treatment of pneumococcic meningitis with penicillin compared with penicillin plus aureomycin. Arch Intern Med 1951;88:489-94. Wallace JF, Smith RH, Garcia M, Petersdorf RG. Antagonism between penicillin and chloramphenicol in experimental pneumococcal meningitis. Antimicro

Agents Chemother 1966;439-44.
5 Mathies AW, Leedom JM, Ivler D, Wehsle PF, Portnoy B. Antibiotic antagonism in bacterial meningitis. Antimicrob Agents Chemother 1968:218-24.

(Accepted 6 fune 1985)

Faculty of Medicine, Chinese University of Hong Kong, Prince of

Wales Hospital, Shatin, New Territories, Hong Kong

G L FRENCH, BSC, MRCPATH, professor of microbiology

T K W LING, BSC, scientific officer, department of microbiology

D P DAVIES, FRCP, DCH, professor of paediatrics

D T Y LEUNG, MRCP, DRCOG, lecturer in paediatrics

Correspondence to: Professor French.

\section{Reversal of liver damage due to long term methyltestosterone and safety of non-17 $\alpha$-alkylated androgens}

Long term androgen treatment may lead to various patterns of liver damage including cholestasis, peliosis hepatis, nodular regenerative hyperplasia, and primary hepatic tumours. ${ }^{12}$ In 1977 we described a series of patients with liver damage due to long term methyltestosterone. $^{3}$ We now report a follow up study of some of these patients (those traceable) after they had stopped this drug, as well as a survey of patients receiving long term treatment with non-17 $\alpha$ alkylated androgens, which are said to be free from hepatotoxicity.

\section{Patients, methods, and results}

We studied 42 patients ( 34 female to male transsexuals and eight impotent men) None took excess alcohol ( $>80 \mathrm{~g} /$ day). All were examined physically, and blood was taken for liver function tests. Liver scintiscans with sulphur colloid labelled with technetium- $99 \mathrm{~m}$ were performed in most patients. The series was divided into three groups (table). Tests of significance were derived from the binomial test.

Group 1-Six patients had taken methyltestosterone $(50 \mathrm{mg}$ thrice daily) lone for a mean of 1.3 (SD 0.6 ) years. During treatment all had had abnormal liver function and four abnormal liver scans. Liver biopsy in two had shown sinusoidal dilatation, hepatic vein lesions, and cholestasis. When restudied two to four (mean $4 \cdot 1$ ) years after stopping methyltestosterone all six patients had normal liver function and liver scans, although in one uptake of colloid into the spleen was still slightly increased.

Group 2-Eighteen patients originally given methyltestosterone $50 \mathrm{mg}$ thrice daily had been changed to an alternative androgen preparation. Fifteen had received methyltestosterone for between three months and five years (mean $2 \cdot 3(1 \cdot 3)$ years) before being transferred to sublingual testosterone $30 \mathrm{mg}$ thrice daily for one to four years (mean 3.15 (1.4) years) before reassessment. Eight of these patients had had abnormal liver function and scans, and five of these eight had shown androgen related changes on liver biopsy. Liver function and scans were normal in all eight when reviewed during treatment with sublingual testosterone. A further three of these 15 patients had had only abnormal liver function during treatment with methyltestosterone, which returned to normal with sublingual testosterone. Liver function and scans had been normal in four of the 15 patients and remained so during treatment with sublingual testosterone, although in one patient the scan showed increased uptake of colloid into the spleen. The other normal liver scans remained unchanged. The remaining three of the 18 patients had received methyltestosterone for a mean 2.8 years and were then given a parenteral non-17 $\alpha$-alkylated androgen for a mean of 4.5 years. One patient had normal liver function and scan while taking both methyltestosterone and Sustanon 250 (testosterone propionate $30 \mathrm{mg}$, testosterone phenylpropionate $60 \mathrm{mg}$, testosterone isocaproate $60 \mathrm{mg}$, and testosterone decanoate $100 \mathrm{mg} / \mathrm{ml}$ ). The two others had had abnormal liver function and scans, which returned to normal during treatment with either Sustanon 250 or testosterone oenanthate.

Group 3-Eighteen patients were treated solely with sublingual testosterone $30 \mathrm{mg}$ thrice daily for between 10 months and six years (mean $3 \cdot 1$ (1.8) years) They all had normal liver function, but four had slightly enlarged spleens with increased uptake of colloid on scintiscanning.

\section{Comment}

These results suggest that liver damage induced by methyltestosterone is reversible, in agreement with occasional previous reports. We found no evidence of hepatic damage due to long term treatment with non-17 $\alpha$-alkylated androgens, which are traditionally regarded as free from hepatotoxicity. Electronmicroscopical abnormalities in the bile canaliculi and increased retention of sulphobromophthalein have, however, been described, ${ }^{4}$ although they appear to be much less common than with $17 \alpha$-alkylated compounds. Recently bile duct proliferation, peliosis, and cholangiocarcinoma were reported in a series of patients treated with non-17 $\alpha$-alkylated androgens. ${ }^{5}$ The importance of the abnormal spleen image found in some of our cases is not clear, although peliosis may affect the spleen and spare the liver.

Although our findings are reassuring, we recommend careful long term surveillance of patients taking non-17 $\alpha$-alkylated androgenic and anabolic steroids; isotopic or ultrasound imaging is advisable in addition to liver function tests.

We are indebted to Dr Ashley Robin for his support; to a series of house physicians, who have helped with the investigation of these patients; and to Dr K D MacRae for his help with the statistical analysis.

1 Ishak KG. Hepatic lesions caused by anabolic and contraceptive steroids. Semin Liver Dis 1981;1:116-8.

2 Paradinas FJ, Bull TB, Westaby D, Murray-Lyon IM. Hyperplasia and prolapse of hepatocytes into hepatic veins during longterm methyltestosterone therapy: possible relationships of these changes to the Westaby D, Ogle ST, Paradinas FJ, Randell JB

urray-Lyon IM. Liver damage from long-term methyltestosterone. Lancet $1977 ;$ ii $261-3$.

4 Nusinovici V. Steroides anabolisants et cholestase. Médecine et Chirurgie Digestives $1974 ; 3: 167-71$

5 Turani H, Levi J, Zevin D, Kessler E. Hepatic lesions in patients on anabolic androgenic therapy. Isr $\mathcal{F}$ Med Sci 1983;19:332-7.

(Accepted 3 fuly 1985)

Gastrointestinal Unit, Charing Cross Hospital, London W6

C P LOWDELL, BSC, MRCP, medical registrar

IAIN M MURRAY-LYON, MD, FRCP, consultant physician and gastroenterologist

Correspondence to: Dr Murray-Lyon.

Patients with abnormal liver function and isotope liver scans during treatment with methyltestosterone $(M T)$ and after stopping treatment (group 1) or substitution of a non-17x-alkylated androgen (group 2). Group 3 were given testosterone only

\begin{tabular}{|c|c|c|c|c|c|c|c|}
\hline & \multicolumn{3}{|c|}{ Group 1} & \multicolumn{3}{|c|}{ Group 2} & \multirow{2}{*}{$\frac{\text { Group } 3}{\text { Testosterone only }}$} \\
\hline & During MT & No treatment & $\mathrm{p}$ Value & During $M T$ & $\begin{array}{l}\text { Other androgen } \\
\text { treatment }\end{array}$ & $\mathrm{p}$ Value & \\
\hline $\begin{array}{l}\text { Abnormal liver function } \\
\text { Abnormal scan }\end{array}$ & $\begin{array}{l}6 / 6 \\
4 / 6\end{array}$ & $\begin{array}{l}0 / 6 \\
1 * / 6\end{array}$ & $\begin{array}{l}0.032 \\
0.25\end{array}$ & $\begin{array}{l}13 / 18 \\
10 / 18\end{array}$ & $\begin{array}{l}0 / 18 \\
1 * / 18\end{array}$ & $\begin{array}{l}0.0002 \\
0.004\end{array}$ & $\begin{array}{l}0 / 18 \\
4^{*} / 18\end{array}$ \\
\hline
\end{tabular}

-Patients had enlarged spleens with increased uptake of colloid. 